\title{
Enabling entrepreneurial behaviour in a land-based university
}

\author{
by Manning, L.
}

Copyright, Publisher and Additional Information: This is the author accepted manuscript. The final published version (version of record) is available online via Emerald Publishing.

This version is made available under the CC-BY-ND-NC licence:

https://creativecommons.org/licenses/by-nc-nd/4.0/

Please refer to any applicable terms of use of the publisher

DOI: https://doi.org/10.1108/ET-03-2017-0036

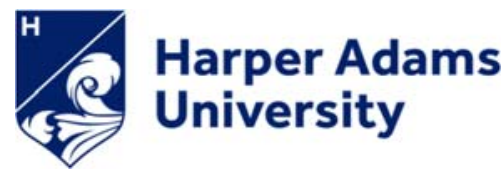

Manning, L. 2018. Enabling entrepreneurial behaviour in a land-based university. Education and Training. 


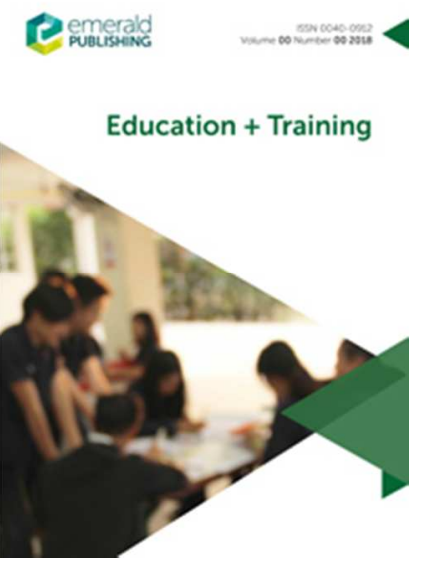

\section{Enabling entrepreneurial behaviour in a land-based university}

\begin{tabular}{|r|l|}
\hline Journal: & Education + Training \\
\hline Manuscript ID & ET-03-2017-0036.R2 \\
\hline Manuscript Type: & Review Paper \\
\hline Keywords: & $\begin{array}{l}\text { entrepreneurial intention, attitude, behaviour, student, academic, } \\
\text { entrepreneurial }\end{array}$ \\
\hline \multicolumn{2}{|l}{} \\
\hline
\end{tabular}

SCHOLARONE ${ }^{\text {I }}$

Manuscripts 


\section{Abstract}

Purpose: The aim of this paper is to develop a conceptual framework along with a set of hypotheses that reflects the dynamic relationships that operate within an entrepreneurial landbased university in order to then undertake empirical research.

Design/Methodology: This paper, through reflection on existing literature, critiques the interactions between student, academic, educational institution and industry in order to conceptualise the entrepreneurial modus operandi of a land-based university.

Findings: Specialist universities, such as those that serve the land-based sector, need to demonstrate multiple excellences not only in terms of the education they provide for students, but also in terms of consistently meeting or exceeding government, research community, employers, and societies expectations. An institutional framework must be in place to facilitate and enhance the quadruple interface of academic, institutional, industry and student entrepreneurial behaviour. The social and economic factors that mediate the dynamics within this framework firstly underpins student development and supporting them to reach their potential, secondly informs teaching excellence and research practice, and finally leads to outcomes that contribute to the global, national and regional economy.

Originality/value: This paper is of value for those working in the educational sector as the model outlined can be used to critically reflect on current principles and practice and derive options for action to embed entrepreneurship more deeply within the organisational culture of a university.

Key words: entrepreneurial intention, entrepreneurial behaviour, student, academic, entrepreneurial competence

\section{Conceptual Paper}

\section{Background}

Entrepreneurial education has evolved as a prominent educational field that includes the disciplines of economics, management, education and technical topics (Maresch et al., 2016; Davidsson, 2008). Entrepreneurial education should focus on individuals experiencing 
entrepreneurship rather than just academics teaching knowledge (Haase and Lautenschläger, 2010); requiring the integration of entrepreneurial education across all disciplines and all activities (Bikse and Riemere, 2013). Based on the assumption that entrepreneurial attributes are not necessarily innate, entrepreneurial skills based education is being introduced in universities and in some study disciplines sees a small rise (1-4\%) in the rates of selfemployment amongst university graduates (Maresch et al., 2016; Premand et al., 2016). Entrepreneurial university is not a new concept, the Massachusetts Institute of Technology (MIT) developed entrepreneurial activity and industry spin offs from the 1930s (Etzkowitz and Zhou, 2008). The entrepreneurial university results from a change in focus from being on teaching to instead one of research with competitive tendering for research funding (Etzkowitz, 2003), and seeking to access a greater range of funding sources including private finance (Clark, 2001). Jacob et al., (2003:1555) describe university based entrepreneurship as firstly commercialisation, for example consultancy services and extension activities, and secondly commodification, including patents, licensing, and faculty or student owned startups. Bramwell and Wolfe (2008) consider that the suggestion that research can be commercialised is mechanistic and demonstrates a misunderstanding of the process involved and the role that the university needs to play. Instead they argue universities form a focal point for talent generation, provision of technical support, expertise and facilities and enable access to knowledge in a broader context rather than just consideration of simple, linear knowledge transfer.

Etzkowitz (2004) proposes the "triple helix" interaction between university-industrygovernment driving innovation in an increasingly knowledge based society. Governments promote this academic transition as an economic development strategy that also reflects changes in the relationship between knowledge producers and users (Etzkowitz et al., 2000: 313). Clark (2001) sees entrepreneurial university as an opportunity to develop new forms of knowledge, new problem solving skills and new types of students. Graduates may, as a result, display personal and organisational entrepreneurial capacities that underpin effective business development and also social entrepreneurial capacities that relate to cultural sensitivity, and social engagement with work, family and community (Gibb and Hannon, 2006). However, in order to commercialise and commodify knowledge, entrepreneurial universities require the infrastructural support mechanisms necessary for enabling organisational entrepreneurship at the same time as they promote entrepreneurship as a product (Jacob et al., 2003).

Entrepreneurship is widely believed to be the main catalyst for growth of an economy 
and has become a key subject in secondary and tertiary education, offering promise for multiple stakeholders (Ishmail et al., 2015; Mat et al., 2015; Dahalan et al., 2013). Entrepreneurship pertains to the actions of a risk taker, undertaking a creative venture, with notions of individuals being seen as having characteristics of individualism, drive, intuition, being highly motivated, creative, and energetic (Obembe et al., 2014; Hébert and Link 1988; Hisrich, 1986; Ehrlich, 1986). Schumpeter (2000) describes the entrepreneur as being creative, operating both as the inventor i.e. the originator of new knowledge and also the innovator that is the introducer of that knowledge in practice or to the market. In much of the literature, the term "entrepreneurship" is interposed with the term "self-employed" (Escribano and Casado, 2016; Bagheri and Pihie, 2010), which includes both profit orientated and nonprofit based concepts of activity. Socially based concepts of self-employment include notions of working for oneself, intellectual and business freedom, as well as choice as to how a person's time is spent and an autonomy over the management of the work: life balance. Social entrepreneurship encapsulates the activity of individuals who seek to be change agents and, through the social networks they generate, introduce entrepreneurial, creative thinking to address existing challenges and problems and deliver stakeholder and societal value (Lans et al., 2014).

Rural entrepreneurship is defined as "the creation of a new organisation that introduces a new product, serves or creates a new market, or utilises a new technology in a rural environment" (Wortman, 1990). Thus rural entrepreneurship can be described as the innovative activities undertaken to address socio-economic issues such as food security, population growth, urbanisation, freshwater use, and effective soil management as well as those social issues affecting rural communities and rural places (Shields, 2005). Historically, agriculture has been considered as an inflexible, low-tech industry dominated by family businesses that are mostly focused on doing things better rather than doing new things, although market influences mean that entrepreneurial behaviour is often seen as an asset within the sector (Lans et al., 2015). Indeed, entrepreneurship is vital for economic transformation, stimulation of global development and is a wealth generator at individual, regional, national and international levels (Obembe et al., 2014; Manning and Parrott, 2018). In the case of land-based universities, consideration of what rural entrepreneurship encompasses is of interest. Land-based educational institutions provide education and training for rural economies from entry level to postgraduate studies and specialise in subject areas such as agriculture, agri-food, animal studies, land management, veterinary services, and 
wildlife management (AOC, nd; Ofsted, 2014). The focus of a land-based university specifically, is not only market-centred entrepreneurship, but also wider concepts of social entrepreneurship, whether that is entrepreneurial and creative activity with regard to delivering public good through land use, or the role of land and rural communities in producing food and amenities that underpin wider public benefit in terms of responsible soil and water management (Jolly, 2012). This paper differentiates between two types of entrepreneurship namely: market-centred entrepreneurship, alternatively described as profitorientated entrepreneurship, and secondly social entrepreneurship where the former is about profit generation and the latter considers people, their problems and the determining of long term solutions (Kummitha and Majumdar, 2015; Austin et al., 2003). Social entrepreneurs generate community associations and networking activities that generate social outcomes (Farmer and Kilpatrick, 2009) and associated social benefit.

Each entrepreneurial university will have its particular "region of influence", and also associated challenges that its stakeholders need to address (Mirani and Yousef, 2016). Whilst the historic model for universities has been one of conventional teaching and research activities (aimed at producing formal academic knowledge that is published in academic journals), an entrepreneurial university needs to be bureaucratically flexible enough to engage with industry in terms of intellectual property, products, services, joint ventures and so forth (Styhre and Lind, 2010). In order to take advantage of entrepreneurial opportunities, the conventional, bureaucratic university structure has to soften into fluid or hybrid forms and become less compartmentalised (Styhre and Lind, 2010); and meet three excellence criteria in teaching, research and institutionally embedding entrepreneurship simultaneously (Guerrero et al., 2015). The institutional element of the entrepreneurial university provides the frameworks and structures for creating spin-off businesses, mediating the academic-industry, academic-student, student-academic, and student-industry interfaces, commercialising ideas and using this process to deliver research informed and industry focused teaching and experiential learning opportunities (Mason and Arshed, 2013). This discourse has been summarised (see Figure 1).

Take in Figure 1

Styhre and Lind (2010:107) state that "rather than solely being a provider of teaching and research, that is, research within formal or theoretical domains of interest, the university is being portrayed as a repository of know-how which should preferably be tapped more effectively." Thus the university as a business model is seen as delivering more than 
simply knowledge and novel research. Instead, universities are increasingly considered to be centres of economic development and growth. The aim of this paper is to contextually explore the notion of rural entrepreneurship and also entrepreneurial behaviour in agricultural and food supply chains and wider landscape management and more especially the role of the specialist university as a catalyst within this process. A further objective of this paper is to provide a conceptual underpinning to ongoing empirical research in the area of entrepreneurial activity in the university setting and the nuances of the quadruple interaction of student, academic, industry and finally the institutional character of the university itself. The paper is structured into five segments which include: the background, and review of related literature, conceptualization of a model and then a discussion and conclusion that highlights the potential for future primary research in this area.

\section{Entrepreneurial intention and the role of the student}

Behavioural models such as the theory of planned behaviour or TPB (Fishbein and Azjen, 1975) have been used in a wealth of published literature to seek to explain farmer intentions, attitudes and market-orientated behaviours (Beedell and Rehman, 2000), as well as their willingness to engage in social entrepreneurship activities. One factor that is context specific to a land-based university is social learning for students through their family situation i.e. their interaction with self-employment, and entrepreneurship within the family social context, for example, family farming or other self employed status. Shirokova et al., (2015) state there is a significant positive association between entrepreneurial intention (EI) and the scope of start-up activities that student entrepreneurs are engaged in. Factors that reinforce that association were family entrepreneurial background (Küttim et al., 2014), age, being male rather than female, and the university entrepreneurial environment. Jaskiewicz et al., (2015: 30) introduce the notion of entrepreneurial legacy arguing that entrepreneurial legacy is derived from being involved with a farming business from birth and then active involvement in a family context. This notion of entrepreneurial legacy is relevant to farming businesses that form the majority of businesses in the land-based sector with entrepreneurial bridging playing a part in nurturing entrepreneurship in younger generations as multiple generations work side by side in the family business; and families with an entrepreneurial legacy nudging their children toward educational and work experiences that are both high quality and related to the family business and potential future opportunities (Jaskiewicz et al., 2015; Manning and Parrott, 2018). Ambad and Damit (2016) suggested perceived relational support and Mat 
et al., (2015) access to capital, information and social networks all influence EI. Thus when considering the student body, some students may start at a land-based university with the influence of entrepreneurial legacy and be within the learning environment, with those who conversely have not. This will influence, but not exclusively, their EI as individuals and as a collective group within the classroom setting. Therefore the academic is engaging with a range of experience, and attitudes, when seeking to explore entrepreneurial topics with students. Ambad and Damit (2016) conclude that three factors influence EI: perceived relational support (PRS) that is the greater the support from people around them e.g. parents, family, friends, network, the greater the student's EI suggesting both entrepreneurial legacy and social learning; perceived behavioural control (PBC) the easier the student believes it would be to become an entrepreneur the more motivated they are to be entrepreneurial themselves again posing the question about the influence of social learning; and entrepreneurial attitude (EA) the greater the attractiveness of entrepreneurship to the student, the greater the EI.

Camelo-Ordaz et al., (2016) considers entrepreneurial self-efficacy, a concept derived from Social Learning Theory (SLT), whilst others have described this characteristic as entrepreneurial orientation (EO), see Ishmail et al., (2015). Self-efficacy reflects an individual's perception of, and their degree of personal confidence in, their own skills, abilities and competence, the ability in individuals to recognise opportunities, and fear of failure, proactiveness, innovativeness, risk tolerance and risk aversion in terms of willingness to be self-employed are all important considerations (Camelo-Ordaz et al., 2016; Kickul et al., 2008; Bandura, 1989). The ability to recognise opportunities to start a business, or make the most of a commercial situation, is positively related to EI, with a gender influence as previously highlighted in this paper, the effect being stronger in the case of males but whether this is due to EA, PBC or PRS is unclear (Camelo-Ordaz et al., 2016; Langowitz and Minniti, 2007).

Obembe et al., (2014) found in their work there was no difference by gender in terms of perceptions of entrepreneurship. Karimi et al., (2013) considered the relationship was more complex and that whilst gender did not influence PBC and EI, gender did affect firstly EA, which was weaker for females, and that subjective norm ( $\mathrm{SN})$ was a stronger predictor of EI for female students than for male (Manning and Parrott, 2018). Dahalan et al., (2013) assert that males and females just have a different way of thinking associated around how they value life and this will influence gender specific perceptions of entrepreneurship and its value. Camelo-Ordaz et al.'s (2016) work found that it was social learning that may influence 
female self-perceptions and, as a result, restrict their EI and thus that there is a relationship between EO and EI.

The rationale, often used in education when disseminating entrepreneurial principles, is that in order to drive entrepreneurial behaviour and outcomes, students must study and acquire appropriate entrepreneurial knowledge and information (EKI), and that this will then influence their EA then EI i.e. the willingness to start a new business when they leave university (Mat et al., 2015). These learning informed steps will then in turn through exhibiting entrepreneurial behaviour drive increasing entrepreneurial competence. Entrepreneurial competence is "the totality of an individual's personal abilities, qualities and skills that ensures successful entrepreneurship" (Bikse and Riemere, 2013: 511). Entrepreneurial competence as a characteristic involves the capability of introducing creativity and innovation, abilities and skills such as effective communication, organisation, project management, action planning and risk-taking as well as the knowledge and skills needed for establishing and developing a new enterprise (Bikse, 2011). By contrast, the student can be seen as a passive recipient of EKI or conversely, the student can be determined as a co-creator of EKI, by actively constructing their own knowledge and meaning (Mueller and Anderson, 2014). This suggests there is a role within the learning process to embed EKI through specific learning opportunities, thus promoting EI, entrepreneurial competence and subsequently entrepreneurial behaviour either during their studies and/or when they exit university into the wider economy. Indeed, in a multiple co-creation process the capital value of EKI is increasing not only just within the student body, but also within the academic body. The themes outlined here have been drawn together (Figure 2) into an entrepreneurial behaviour model (EBM).

\section{Take in Figure 2}

However, as various behavioural models including the TPB highlight, knowledge generation and EI in themselves will not necessarily lead to entrepreneurial behaviour. This suggests that a framework needs to be built within the wider construct of land-based entrepreneurial education to facilitate the transformation process. It is important, when developing such frameworks to consider the contextual landscape in which an entrepreneurial university operates and the interaction between the institution itself and the academic, student and industry (Figure 2). At its best this interaction supports both industry focused and research informed teaching and the benefits to the students of industry-related opportunities such as work placement and business sponsorship. Whilst public funding for novel research is 
an inherent element of entrepreneurial universities, also undertaking more applied and nearmarket research activity affords the opportunity for private research funding, consultancy and commercialisation activities such as business spin-offs. There is an underpinning value in this near-market research activity in terms of building EI across the university itself and within the academic and student bodies.

\section{Take in Figure 2}

Therefore it could be proposed that within the entrepreneurial university setting EI does not just rest with the student body, but also with academics, the institution itself and the industry partners with whom the university interacts and these interactions are now explored in the wider context of entrepreneurial education.

\section{The role of the academic and the university institution in promoting entrepreneurship}

Academic entrepreneurship describes the involvement of academics in commercial activities in addition to teaching and research (Mirani and Yusof, 2016). The academicindustry interface promotes the capitalisation of knowledge and this has the potential to increase university revenue (Ishmail et al., 2015). However, the role of the academic migrates to being knowledge provider, coach or knowledge developer (Mueller and Anderson, 2014), catalyst, change agent, and/or thought leader. Barriers associated with university culture that impinge on academic entrepreneurial activity, and subsequent commercialisation of research are characterised by inertia, non-cooperative attitude, weak or few incentives, conflict between contemporary and traditional needs of academia and un-supported infrastructure (Ishmail et al., 2015; Usaci, 2015). Further, Chang et al., (2016) suggests the situation is more complex and that "trade-offs occur at the different levels of the organisation" in respect of a research duality that they term "research ambidexterity" and whilst there is a goal to achieve high-ranking, world leading, research publications, also there is increasing pressure for the academics to deliver in the area of research commercialisation with the resultant negotiation around intellectual property rights, timescales and funding. Others propose ambidexiterity in terms of scientific knowledge and technology outputs (D'Este and Perkmann, 2011; Ambos et al., 2008). Entrepreneurial universities transfer technology in order to create entrepreneurial thinking, developing actions, institutions and entrepreneurial capital in an entrepreneurial society (Mirani and Yousof, 2016; Audretsch, 2014). Thus, university orientated technology transfer includes the commercialisation of scientific or academic knowledge, academics participating in consultancy, transformation of that 
knowledge into products and services, increasing economic growth and development at a regional or wider scale, (Mirani and Yousef, 2016). For commercialisation of academic research to succeed, processes must be in place to ensure the EO-EI linkage (Ishmail et al., 2015), so there needs to be a clearly defined institutional entrepreneurial intention (IEI) at governance level, that provides a fertile environment for both academic entrepreneurial intention (AEI) and student entrepreneurial intention (SEI). By inference this narrative promotes that increasing human capital is crucial.

D'Este and Perkmann (2011) argue that academics, rather than simply focusing on 'blue-skies' research, engage with industry partners primarily to support their research activities. However this interaction is influenced by the nature of the academic-industry affiliation in terms of the degree of commercialisation, the potential for increased knowledge, access to funding and access to in-kind resources. Mechanisms to increase both students' and academics' confidence in their own skills, abilities and competence (student entrepreneurial competence (SEC) and academic entrepreneurial competence (AEC)), as well as their collective ability to consider risk, fear of failure and to recognise opportunity must be embedded within the institutional entrepreneurial framework fusing the "EI quandrant" of SEI, AEI, IEI and externally industry's entrepreneurial intention too. This approach will ensure teaching and research is both independently and collectively entrepreneurially aligned.

Within the institutional setting, discrete social constructs will affect the "EI quadrant". It can be theorised that science and engineering students through post university marketcentred entrepreneurial activities create organisations that provide the best financial return and job growth. However there is little literature to support this (Maresh et al., 2016). In their work on EI, Maresch et al., note that EI is influenced by age, and gender and that business students have a higher degree of EI than engineering and science students although in part this could be attributed to the lower level of entrepreneurial education in the curriculum for engineering and science students. As well as gender, wider influencers of social construct in terms of culture and $\mathrm{SN}$ will also have a role in influencing individuals (both students and academics) to engage in entrepreneurial behaviour. Indeed factors such as faculty members being involved in entrepreneurial activity, innovative programmes and research orientated culture all having a mediating role (Ismail et al., 2015). This review of literature has led to consideration of the multiple interactions that occur within the entrepreneurial university that influence and catalyse entrepreneurial behaviour in students, academics and also in terms of the institution and its own structures and dynamics that influence its entrepreneurial competence and resultant entrepreneurial behaviour. As a result a conceptual model has been 
developed (Figure 3). The outer influence of industry and other stakeholders is not included within this internal interaction model.

\section{Take in Figure 3}

The elements of the model proposed in this paper are now reviewed in terms of the role of the academic, the role of the curricula and the role of the social constructs in promoting entrepreneurship. Whilst the Ambit and Damit (2016) study considers SEI, this literature translates to consideration of AEI as well. Ishmail et al., (2015) highlight that academic associated characteristics such as AEI, prior academic entrepreneurial experience, industrial experience and research focus directly influence SEI and by interference also AEI in the academics themselves. Usaci (2015) terms AEI as professional entrepreneurial intentions (PEI) and this links too within the entrepreneurial education and entrepreneurial university construct and wider IEI (see Figure 3). Camelo-Ordaz et al., (2016: 13) assert that the role of entrepreneurial education "only seems to be relevant when it comes to enhance the likelihood of non- entrepreneurs exhibiting EI'. However, research has shown that entrepreneurial education increases EI, however different student groups may require different academic action (Maresch et al., 2016). Gonzalez-Alvarez and Solis-Rodriguez (2011) assert that knowledge acquired through experience and practical learning gives individuals greater cognitive capacity leading to them being able to identify EO i.e. that EO has a positive relationship with human capital attributed to such constructs as social networks, learning and work experience. Thus it could be argued entrepreneurial education needs to provide within the curricula both experiential and practical learning opportunities, such as work-placements, in order to drive EO. This is as true for the students as with academics and their professional development programmes that are adopted within the entrepreneurial education setting.

Inclusion of entrepreneurial elements within the curricula could translate into highly employable graduates as well as boosting the economy (Mat et al., 2015). EC is developed during the entrepreneurial education process (Bikse and Riemere, 2013), but they contest that the term entrepreneurial education is often understood in what is a narrow context, namely business activity and economics, whereas it could be argued entrepreneurial education is a much wider construct that influences not only SEC but also AEC too. Entrepreneurial education must have a distinct pedagogy that links with syllabus and co-curricular activities to embed work-related learning, active and experiential learning, social interaction learning, action learning and entrepreneurial training (Kadir et al., 2012; Bagheri and Pihie, 2010). Mueller and Anderson (2014) construct from their research what they consider to be the major 
stages of the entrepreneurial learning process: engaging through responsibility for personal learning; learning through social exchange, a socialised process in a low-risk environment that allows connecting to self, others and the world; independent thinking as a result of individual need and social change; and entrepreneurial learning and personal development in a dynamic process. This introduces aspects of criticality into the learning experience.

Bagheri and Pihie (2010) note in their research on entrepreneurial education that whilst the majority of students highlighted real and active tasks as the most influential factors for enhancing entrepreneurial leadership, for other students capabilities were learned through social interaction, observation and reflection as a result of meeting entrepreneurial role models. This suggests a need for a diverse learning environment. Workplace placement opportunities, and internships in organisations that demonstrate excellent entrepreneurial characteristics are also a fertile learning environment (Manning and Parrott, 2018). Individual and collective reflection was also seen to be of value, by students in the Bagheri and Pihie study, promoting the use of reflective learning with peers in a facilitated environment within the entrepreneurial education framework. Therefore entrepreneurial learning and experimentation is a developmental process which is designed to develop the entrepreneurial maturity of individuals, with the learning environment accommodating uncertainty, change and individual development albeit that this is challenging within current the administrative, organisational and political boundaries of most educational institutions (Mueller and Anderson, 2014). Karimi et al., (2013) propose that entrepreneurial universities must be sensitive to diversity, including by gender and career choice as this influences the benefits derived by individual student that coalesce around entrepreneurial education. Further, they argue to maximise the effectiveness of entrepreneurial education and to drive EI, curricula must be focused so that students that are motivated by instrumental factors (normally male) and those that are engaged through social factors (normally female) have their individual learning needs met. The critique of literature here demonstrates the value of considering curricula design in providing opportunity for learning experiences both in the wider construct as shown in Figure 1, and the individual level Figure 2.

\section{Discussion}

Entrepreneurship is vital for both personal and economic development. An entrepreneurial university is required to embed entrepreneurship in all they do and to combine this in both their teaching and their research and underpin IEI and IEC as these inform both 
SEI and AEI. Chang et al., (2016) raise the concern that there are always trade-offs occurring at different levels of the organisation between teaching, pure and applied research. This can create tension as resources are allocated according to market demand and policy drivers. The paper has considered the mechanisms that universities can employ to use entrepreneurship to inform teaching practice undertake pure and applied research and contribute to the global and national and regional economy. The research on the barriers to academic entrepreneurial activity highlight that if IEI and IEC is not strong and if there is weak infrastructure there can be few incentives to engage with industry, thus limiting entrepreneurship within the institution. This means that where conventional, often bureaucratic institutional structures occur they have to become more fluid in order to take advantage of entrepreneurial opportunity.

As engagement with industry increases, the associated academic skillset required as a result changes and evolves. Whilst negative constraints both in terms of institutional structure, personal engagement and others have been suggested by the literature there are positive steps that can be taken in order to embed entrepreneurial education and enhance the EI of students, academics and the institution itself. The complex interaction of factors of influence within an entrepreneurial university has been drawn together in Figure 3 and the overall ambition for an entrepreneurial university is for students to demonstrate entrepreneurial behaviour. Within the overall internal framework there are three sub-frameworks that interact, those of the student, the academic and the institution and also the interface with industry what has been described in this paper as the EI quadrant.

The aim of the paper was to develop a conceptual framework along with a set of hypotheses that reflect the dynamic relationships that operate within an entrepreneurial landbased university in order to inform future empirical research. One element of primary research will be analysis of what students perceive to be entrepreneurship in the land-based sector and the degree of integration of economic and social elements. The hypotheses that will now be tested using primary qualitative and quantitative research within a land-based institution that seeks to promote entrepreneurial behaviour are:

- H1 - Entrepreneurial legacy and entrepreneurial bridging influences EA in students who come from a background of family business/self-employment.

- H2 - EA is greater in those students who come from a background of family business/self-employment.

- H3 - Industry placement for students increases EA when the students return for their final year of study. 
Further research would also be of value in testing the factors of influence in the entrepreneurial behaviour model (Figure 2) institutionally, and with regard to academics, and students both independently and collectively as represented in Figure 3.

\section{Conclusion}

The sense of being an entrepreneurial university is sector specific, and a dynamic and evolving process that leads to continually re-emergent definitions. Indeed, what it is to be perceived as truly entrepreneurial in say the digital economy, or engineering, will be different to perceptions of entrepreneurship in the food and land-based sector. Therefore stakeholders' perceptions of entrepreneurship is dynamic and the community in which the university is operating will have its own distinct sense of entrepreneurship in terms of meaning, framing and associated dilemmas. In order to embed entrepreneurship at the heart of university mission, the institutional resources and formal structure must provide a framework for the interaction between academic, student, the institution and industry too. Resource allocation between teaching and research, and running the organisation itself, is a constant and multilayered dilemma that sits at the triad of individual academic, university department and at the institutional level as the entrepreneurial university seeks to meet multiple stakeholder demands and be seen by all, to consistently add value. In the changing climate of tertiary education, the challenge for any university is how to deliver simultaneously to multiple constructs, and perhaps counter-constructs, of what is perceived as "value" by a range of stakeholders.

This position paper considers the land-based university specifically and underpins future deductive and exploratory research work to determine the interrelationship between the factors outlined here in this specific educational discipline. There is currently a knowledge gap that needs to be addressed. Why is this knowledge gap of concern? As global population rises there is a need to provide more from food from at best existing resources, or in many regions of the world from depleting resources of available land, soil, water and nutrients. As global populations urbanise and cede to others the responsibility to produce their food the challenge becomes more brittle and required innovative, entrepreneurial solutions. Those students going into the land-based and food production sector whether in farming businesses, land management, wider agribusiness, food processing, retail or food service need to have the ability to think critically and be able to identify their role in both the dilemma of global population rise and in delivering solutions. 
The physical and market environment in which land-based businesses operate is fluid and dynamic and an entrepreneurial mindset will afford business operators the ability to take advantage of opportunities and ensure their businesses remain viable and resilient to market or environmental shocks. In the United Kingdom, the influence of current policy issues such as the BREXIT vote and its impact on future farm subsidy payments and rural support, as well as market and policy initiatives to drive innovation and add value at farm level means that entrepreneurial behaviour within the agricultural and wider land based sector, as a subject, is gaining wider interest. Indeed with the post-BREXIT vote discussions, the narrative of what it is to be a farmer in the UK is becoming more nuanced especially the interplay between farmers being market-orientated or social entrepreneurs.

\section{Conclusion}

This paper has drawn together elements from the literature in order to consider land-based entrepreneurial universities, the multiple stakeholders that they interact with, but more especially specifically students, academics, and the institution itself. In this respect this review paper has been developed to support empirical work rather than be a case study in itself. Further research would be of value in determining whether self-employment and being entrepreneurial are equivalent as has been characterised in some literature or whether it can be asserted that they are different i.e. it is possible to be self-employed without being entrepreneurial? This question reflects the need to undertake qualitative work to explore this question in more detail and to consider the meaning of self-employment and entrepreneurship to individuals themselves. The role of entrepreneurial legacy and its impact on students at a land-based university is also worthy of more exploratory research.

It is also important to note that whilst some students may see entrepreneurial activity as a future career option other students may not perceive their future careers through the lens of entrepreneurship. However, further research work is required to identify whether the landbased university specifically has a student body that has a different profile of career aspirations when compared to the wider university sector. Entrepreneurial university is not a new term, but what it is to be entrepreneurial, and to add value both internally and externally to a diverse set of stakeholders is context-specific and constantly evolving. As a result, entrepreneurial activity that is generated by a university can be characterised in both economic and social terms. What it is to show entrepreneurship in the land based sector will clearly be determined in a different way to another area of commerce. Thus, entrepreneurial 
curricula needs to be grounded in line with the business sectors served, whilst being dynamic and reflect the needs of the academic subjects. Further, in universities that have a specific applied focus, specific learning opportunities that increase EA may improve overall learning experience and the individual personal development of the student. As has been highlighted in the paper some students in a university may arrive with entrepreneurial legacy whilst others may not. Further research into this area will improve the entrepreneurial learning experience for students and ultimately drive greater economic growth and development when those students embark on their careers. The models developed as part of this research are of value to universities as they consider the mechanisms that they need to put in place to support entrepreneurial activity. 


\section{References}

Ambad, S.N.A. and Damit, D.H.D.A. (2016), "Determinants of Entrepreneurial Intention among Undergraduate Students in Malaysia", Fifth International Conference on Marketing and Retailing ( $5^{\text {th }}$ INCOMaR), Procedia Economics and Finance, Vol. 37 108-114.

Ambos, T. C. Mäkelä, K. Birkinshaw, J. and D’Este, P. (2008), “When does university research get commercialized? Creating ambidexterity in research institutions." Journal of Management Studies, Vol. 45 No. 8, pp. 1424-1447.

AOC (Association of Colleges) (nd) Available at: https://www.aoc.co.uk/land-based-colleges (accessed 20 November 2017).

Audretsch, D. B. (2014), "From the entrepreneurial university to the university for the entrepreneurial society". The Journal of Technology Transfer, Vol. 39 No. 3, pp. 313-321.

Austin, J. Stevenson, H. and Wei-Skillern, J. (2003), "Social and commercial entrepreneurship: same, different or both", Entrepreneurship, Theory and Practice, Vol. 30 No.1, pp. 1-22.

Bagheri, A. and Pihie, Z.A.L. (2010), "Entrepreneurial Leadership Learning: In Search of Missing Links," International Conference on Learning Diversity 2010, Procedia Social and Behavioral Sciences Vol.7 No. C, pp. 470-479.

Bandura, A. (1989), "Regulation of cognitive processes through perceived self-efficacy" Developmental Psychology, Vol. 25 No. 5, pp. 729-735.

Beedell, J. and T. Rehman. (2000), "Using Social-psychology Models to Understand Farmers' Conservation Behaviour.” Journal of Rural Studies, Vol. 16 No. 1, pp. 117-127.

Bikse, V. and Riemere, I. (2013), "The Development of Entrepreneurial Competences for Students of Mathematics and the Science Subjects: The Latvian Experience." World Conference on Psychology and Sociology 2012, Procedia - Social and Behavioral Sciences Vol. 82 No. 1, pp. $511-519$.

Bikse, V. (2011), Entrepreneurial abilities, Riga: Art and Design, SIA.

Bramwell, A. and Wolfe, D.A. (2008), "Universities and regional economic development: The entrepreneurial University of Waterloo." Research policy, Vol. 37 No. 8, pp.1175-1187.

Camelo-Ordaz, C. Diánez-González, J.P. and Ruiz-Navarro, J. (2016), "The influence of gender on entrepreneurial intention: The mediating role of perceptual factors." BRQ Business. Research Quarterly 2016, Vol.19 No. 4, pp. 261-277.

Chang, Y-C. Yang, P.Y. Martin, B.R. Chi, H-R. and Tsai-Lin, T-F. (2016), "Entrepreneurial universities and research ambidexterity: A multilevel analysis." Technovation, Vol. 54 No. 1, pp. 7-21.

Clark, B. (2001), “The entrepreneurial university: New foundations for collegiality, autonomy, and achievement." Higher Education Management, Vol. 13 No. 2, pp. 9-23. 
Dahalan, N. Jaafar, M. Asma, S. and Rosdi, M. (2013), "Local community readiness in entrepreneurship: Do gender differ in searching business opportunity”, PSU-USM International Conference on Humanities and Social Sciences, Procedia - Social and Behavioral Sciences Vol. 91 No.1, pp. $403-410$.

Davidsson, P. (2008), The Entrepreneurship Research Challenge. Edward Elgar, Cheltenham.

D’Este, P. and Perkmann, M. (2011), "Why do academics engage with industry? The entrepreneurial university and individual motivations." The Journal of Technology Transfer, Vol. 36, No. 3, pp. 316-339.

Escribano, J.J.G. and Casado, A.B.F. (2016), "Construction of gender differences in the discourse of entrepreneurship. Psychobiological, cultural and familial aspects", Suma de Negocios, Vol. 7 No. 15, pp. 18-24.

Ehrlich, E. (1986), “America Expects too Much from Its Entrepreneurial Heroes” Business Week (July 28): pp. 33.

Etzkowitz, H. and Zhou, C. (2008), "Introduction to special issue. Building the entrepreneurial university: a global perspective." Science and Public Policy, Vol. 35 No. 9, pp. 627-635.

Etzkowitz, H. (2004), "The evolution of the entrepreneurial university.” International Journal of Technology and Globalisation, Vol. 1, No. 1, pp. 64-77.

Etzkowitz, H. (2003). "Research groups as 'quasi-firms': the invention of the entrepreneurial university.” Research policy, Vol. 32 No. 1, pp. 109-121.

Etzkowitz, H. Webster, A. Gebhardt, C. and Terra, B.R.C. (2000), "The future of the university and the university of the future: evolution of ivory tower to entrepreneurial paradigm." Research policy, Vol. 29 No. 2, pp. 313-330.

Farmer, J. and Kilpatrick, S. (2009), "Are rural health professionals also social entrepreneurs?” Social Science and Medicine, Vol. 69, No. 11, pp. 1651-8.

Fishbein, M. and Azjen, I. (1975), "Belief, attitude, intention and behaviour. An introduction to theory and research". Addison-Wiley Reading MA.

Gibb, A. and Hannon, P. (2006), "Towards the entrepreneurial university.” International Journal of Entrepreneurship Education, Vol. 4 No. 1, pp. 73-110.

Gonzalez-Alvarez, N. and Solis-Rodriguez, V. (2011), "Discovery of entrepreneurial opportunities: a gender perspective", Industrial Management and Data Systems, Vol. 111 No. 5, pp. 755-775.

Guerrero, M. Cunningham, J.A. and Urbano, D. (2015), "Economic impact of entrepreneurial universities' activities: An exploratory study of the United Kingdom”, Research Policy, Vol. 44 No. 3, pp. 748-764. 
Haase, H. and Lautenschläger, A. (2010), "The 'Teaching Dilemma' of entrepreneurship, International Entrepreneurship and Management Journal”, Vol. 7 No. 2, pp. 145-162.

Hébert, R.F. and Link, A.N. (1988), The Entrepreneur: Mainstream Views \& Radical Critiques. New York, USA: Praeger.

Hisrich, R.D. (1986), "Entrepreneurship and Intrapreneurship: Methods for Creating New Companies That Have an Impact on the Economic Renaissance of an Area", in R. D. Hisrich (ed.), Entrepreneurship, Intrapreneurship and Venture Capital, Lexington, MA: D.C. Heath.

Ishmail, K. Anuar, M.A. Omar, W.Z.W. Aziz, A.A. Soehod, K. and Akhtar, C.S. (2015), "Entrepreneurial Intention, Entrepreneurial Orientation of Faculty and Students towards Commercialization", $3^{\text {rd }}$ International Conference on Leadership, Technology and Innovation Management, Procedia - Social and Behavioral Sciences, Vol. 181 No. 1, pp. 349 - 355.

Jacob, M. Lundqvist, M. and Hellsmark, H. (2003), "Entrepreneurial transformations in the Swedish University system: the case of Chalmers University of Technology." Research Policy, Vol. 32 No. 9, pp. 1555-1568.

Jaskiewicz, P. Combs, J.G. and Rau, S.B. (2015), "Entrepreneurial legacy: Towards a theory of how some family firms nurture transgenerational entrepreneurship", Journal of Busines venturing, Vol. 30 No. 1, pp. 29-49.

Jolly, D. (2012), Agricultural Policies and the Future of US Family Farming, Available at: http://sfp.ucdavis.edu/pubs/SFNews/Fall99/djagtour/ (accessed 4 December 2017).

Kadir, M.B.A. Salim, M. and Kamarudin, H. (2012), "The Relationship Between Educational Support And Entrepreneurial Intentions in Malaysian Higher Learning Institution", International Conference on Education and Educational Psychology (ICEEPSY 2012), Procedia - Social and Behavioral Sciences, Vol. 69 No. 1, pp. 2164 - 2173.

Karimi, S. Biemans, H.J.A. Lans, T. Chizari, M. Mulder, M. Mahdei, K.N. (2013), "Understanding role models and gender influences on entrepreneurial intentions among college students," 3rd World Conference on Learning, Teaching and Educational Leadership (WCLTA-2012), Procedia - Social and Behavioral Sciences, Vol. 93, No. 1, pp. 204-214.

Kickul, J. Wilson, F. Marlino, D. and Barbosa, S.D. (2008), “Are mis- alignments of perceptions and self-efficacy causing gender gaps in entrepreneurial intention among our nation's teens?" Journal of Small Business and Enterprise Development, Vol. 5 No. 2, pp. 321-335.

Kummitha, R.K.R. and Majumdar, S. (2015), "Dynamic curriculum development on social entrepreneurship - A case study of TISS." The International Journal of Management Education Vol. 13 No. 3, pp. 260-267.

Küttim, M. Kallaste, M. Venesaar, U. and Kiis, A. (2014), Entrepreneurship education at university level and students' entrepreneurial intentions. Procedia-Social and Behavioral Sciences, Vol. 110 No.1, pp. 658-668.

Langowitz, N. and Minniti, M. (2007), "The entrepreneurial propensity of women." Entrepreneuship Theory and Practice, Vol. 31 No. 3, pp. 341-364. 
Lans, T. Seuneke, P. and Klerkx, L. (2015), “Agricultural Entrepreneurship In: Encyclopedia of Creativity, Invention, Innovation and Entrepreneurship.” Publisher: Springer Reference, Editors: Elias G. Carayannis.

Lans, T. Blok, V. Wesselink, R. (2014), "Learning apart and together: towards an integrated competence framework for sustainable entrepreneurship in higher education," Journal of Cleaner Production, Vol. 62 No.1, pp. 37-47.

Manning, L. and Parrott, P. (2018), "The impact of workplace placement on students' entrepreneurial intention," Higher Education, Skills and Work-based learning, Vol. 8 No.1, pp. 1-16.

Maresch, D. Harms, R. Kailer, N. and Wimmer-Wurm, B. (2016), "The impact of entrepreneurship education on the entrepreneurial intention of students in science and engineering versus business studies university programmes," Technological Forecasting and Social Change, Vol. 104 No.1, pp. 172-179.

Mason, C and Arshad, N. (2013), "Teaching entrepreneurship to university students through experiential learning: A case study," Industry and Higher Education, Vol. 27, No. 6, pp. 449463.

Mat, S.C. Maat, S.M. and Mohd, N. (2015), "Identifying Factors that affecting the entrepreneurial intention among engineering technology students," $2^{\text {nd }}$ Global Conference on Business and Social Science - 2015, GCBSS-2015 17-18 September 2015, Bali, Indonesia, Procedia - Social and Behavioral Sciences Vol. 211 No.1, pp. 1016-1022.

Mirani, M.A. and Yusof, M. (2016), "Entrepreneurial Engagements of Academics in Engineering Universities of Pakistan," 7th International Economics \& Business Management Conference, 5th \& 6th October 2015, Procedia Economics and Finance, Vol. 35 No.1, pp. 411-417.

Mueller, S. and Anderson, A.R. (2014) "Understanding the entrepreneurial learning process and its impact on students' personal development: A European perspective,"

The International Journal of Management Education, Vol. 12 No.1, pp. 500-511.

Ofsted (2014), Good practice in land-based education and training Available at http://dera.ioe.ac.uk/19406/1/Good\%20practice\%20in\%201andbased\%20education\%20and\%20training.pdf (accessed 20 November 2017).

Obembe, E. Otesile, O. and Ukpong, I. (2014), “Understanding the students' perspectives towards entrepreneurship," ICGSM 2014, Procedia - Social and Behavioral Sciences, Vol. 145 No. 1, pp. 5-11.

Premand, P. Brodmann, S. Almeida, R. Grun, R. and Barouni, M. (2016), "Entrepreneurship Education and Entry into Self-Employment Amongst University Graduates," World Development, Vol. 77 No.1, pp. 311-327.

Schumpeter, J.A. (2000), "Entrepreneurship as Innovation.” Entrepreneurship: The Social Science View, pp. 51-75 Available at SSRN: https://ssrn.com/abstract=1512266 (accessed 20 November 2017). 
Shields, J.F. (2005), "Does rural location matter? The significance of a rural setting for small businesses.” Journal of Developmental Entrepreneurship, Vol. 10 No. 1, pp.49-63.

Shirokova, G. Osiyevskyy, O. and Bogatyreva, K. (2015), "Exploring the intention-behavior link in student entrepreneurship: Moderating effects of individual and environmental characteristics," European Management Journal, Vol. 34 No. 4, pp. 1-14.

Styhre, A. and Lind, F. (2010), "The softening bureaucracy: Accommodating new research opportunities in the entrepreneurial university," Scandanavian Journal of Management, Vol. 26 No. 2, pp. 107-120.

Usaci, D. (2015), "Predictors of professional entrepreneurial intention and behaviour in the educational field”, PSI WORLD 2014, Procedia - Social and Behavioral Sciences Vol. 187 No. 1, pp. 178-183.

Wortman, M. (1990), “A Unified Approach for Developing Rural Entrepreneurship in the US”, Agribusiness, Vol. 6, No. 3, pp. 221-236 1990. Available at SSRN:

https://ssrn.com/abstract $=1505860$ 


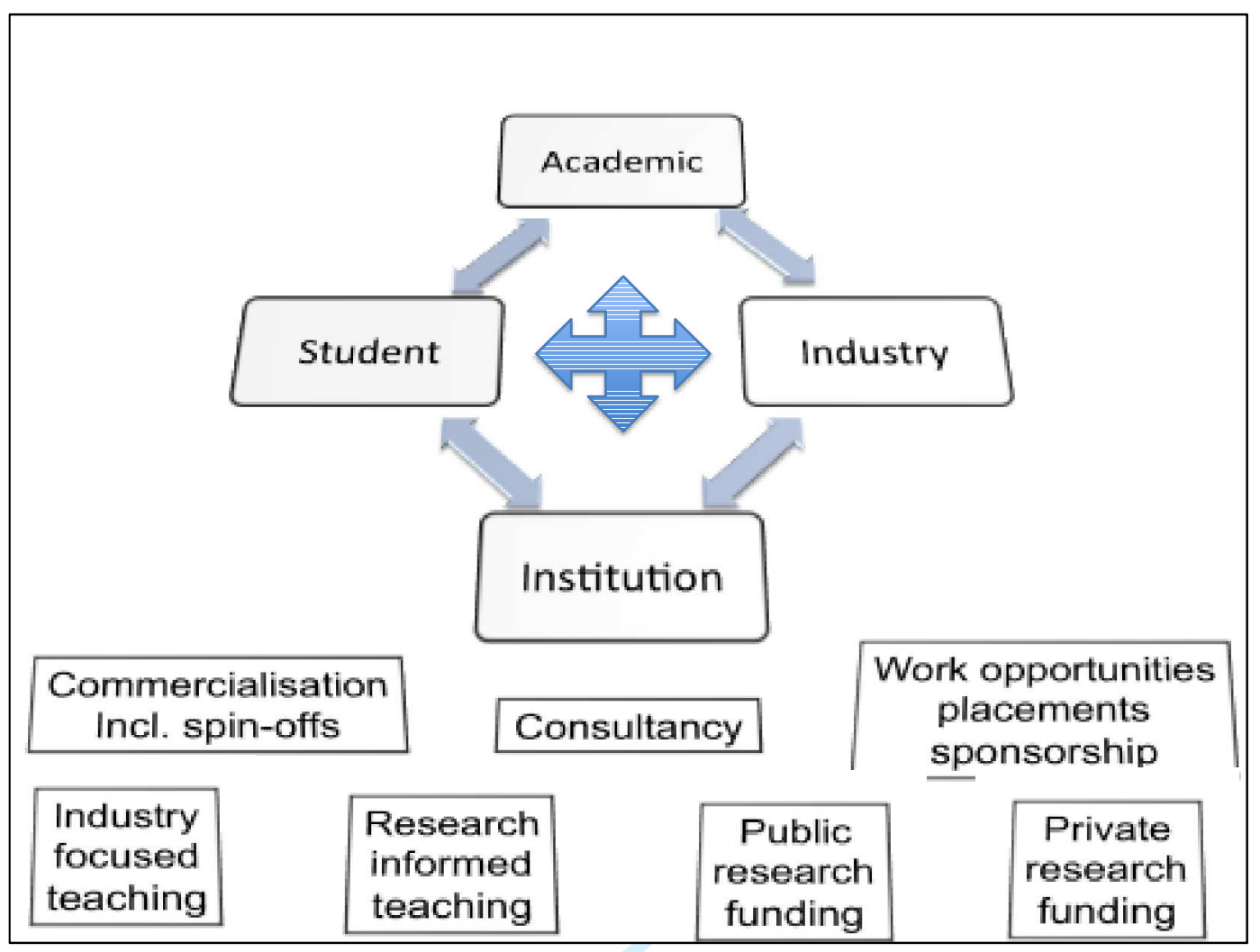

Figure 1. The contextual landscape of an entrepreneurial university

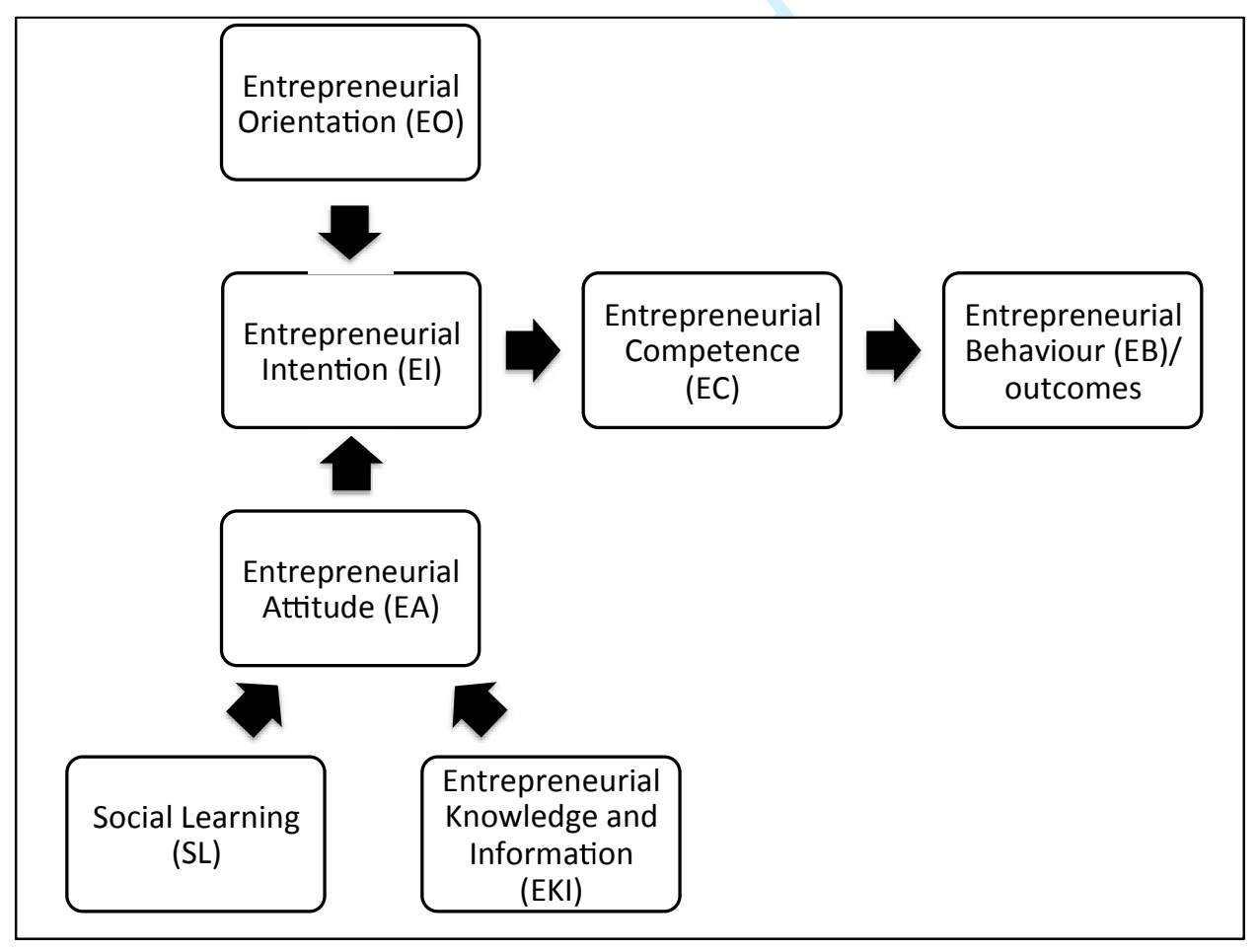

Figure 2. Entrepreneurial Behaviour Model (Manning and Parrott, 2018) 


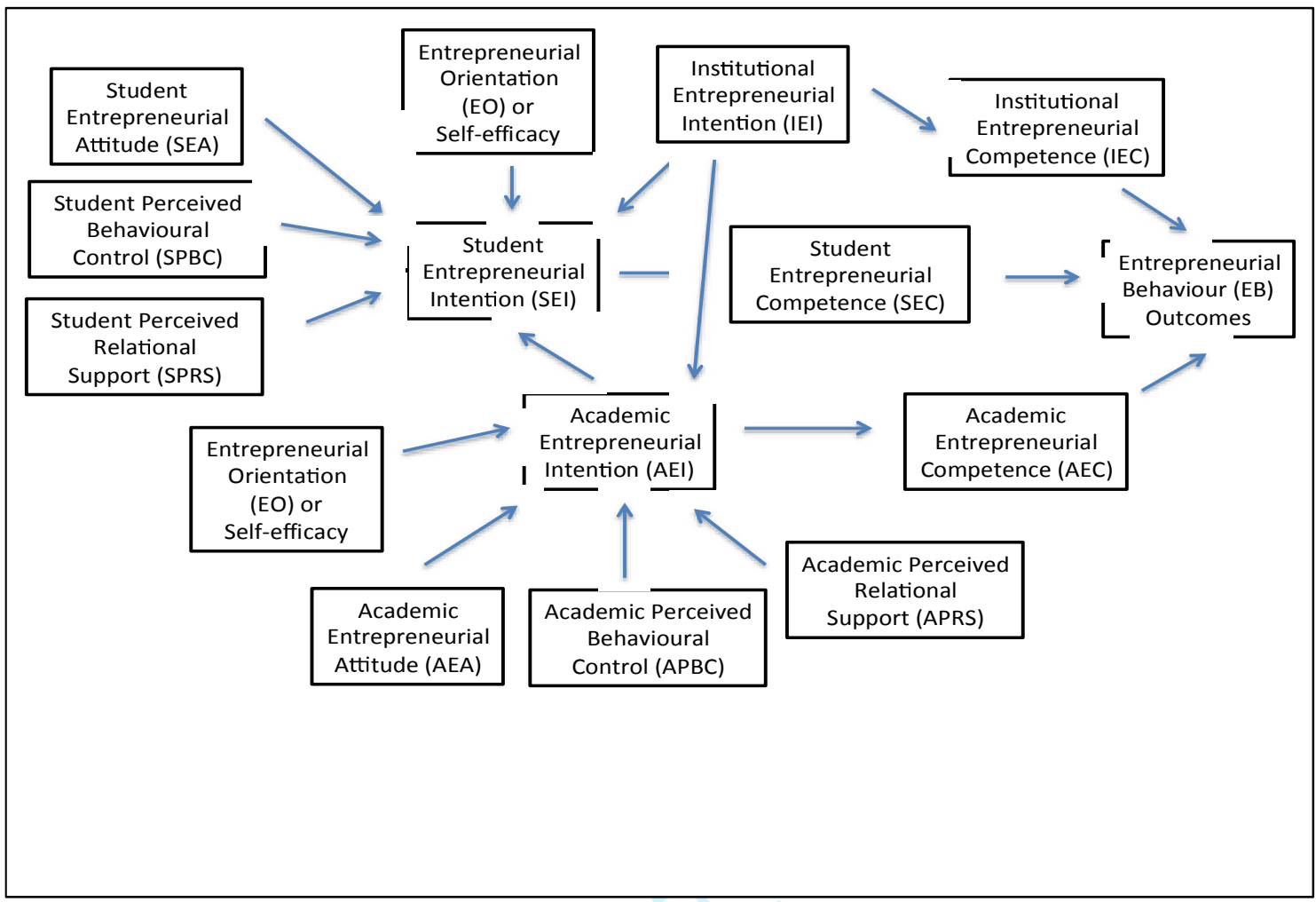

Figure 3. Framework of interaction within an Entrepreneurial University 